plant science to study such subjects as absorption of ions by leaves, uptake of minor elements, photosynthesis and sap movement in trees. The use of isotopes in animal science fell approximately into four categories, namely, intermediary metabolism, mineral metabolism, endocrinology and reproduction.

The fact that the genetic materials-the genes and chromosomes-are highly sensitive to ionizing radiations which induce hereditary changes or mutations has led to the exploration of the possibility of using this technique in improvernent of crops. So far the method has been little used in animal breeding. 'The delegations indicated that useful mutations of cereals and other crops were being obtained.

The Group also discussed the reports which several countries presented on the use of radiation in the preservation and processing of food. This work is still in the developmental stage, and important problems need further investigation. At the moment, the destruction of insects in stored products, the suppression of sprouting in potatoes and root crops and the treatment of some fresh meats would appear to be the most promising applications of ionizing radiation to foods.

The nature of the financial provisions required for research programmes involving the use of isotopes and radiation was discussed, and the delegations made statements on the scope of training facilities for isotope research. Consideration was also given to the design and equipment of isotope laboratories for agricultural research. Attention was directed to the need for an international list of available labelled compounds. For the future, the Group agreed to continue its activity in organizing special meetings or symposia in particular aspects of soil science, plant science, plant breeding, animal science and use of radiation in food preservation.

E. C. Humphries

\section{SCHOOL NATURAL HISTORY SOCIETIES}

$\mathrm{T}$

HE value of voluntary societies to the corporate life of the school and its fuller development is well brought out in three recent reports. The first, from Blundell's School, gives details of special Sunday evening lectures which are arranged by the Science Society and to which speakers of distinction have been invited over a period of many years. The hundredth of the meetings was celebrated during the year under review when the Society proudly welcomed back Mr. W. H. Dowdeswell, who had had much to do with the Society's foundation.

The role of the society in stimulating the pursuit of knowledge and truth for their own sakes is shown by the original investigations which form the bulk of the report. J. H. Becket describes observations made on catches in moth traps placed at ground-level and at a height of $80 \mathrm{ft}$. An account of experiments to compare soil temperatures under glass and polythene eloches with that of unprotected soil is given by W. L. Slater, while investigations of the flora of the Grand Western Canal are cxamined by C. Little. How woodlice maintain themselves in a moist environment has been investigated by A. J. S. Wearing; A. Lamb gives an account of the effieiency of the pollination mechanism in Arum maculatum. There is also a description of pollen and pollination in rhododendrons by A. Ridge.
Much of the report of the Rugby School Natural History Society is taken up with an account by J. A. D. Hope of his ornithological observations on the Isle of May for a short period in 1956. Hope was primarily concerned with records of the plumage and characteristics, voice and behaviour of the shag, the kittiwake and the fulmar; his essay is not unworthy of much more experienced ornithologists. Besides details of special lectures, the report contains information about the activities of the many sections comprising the Society. These include the museum, vivarium, library, zoological and entomological section ; wffiliated sections, the proceedings of which are described, include architecture, meteorology, photography, astronomy, railways, wireless, aeromodelling and philately. The Society has much to be proud of.

This is also true of the Oundle School Natural History Society, the report of which is mainly eoncerned with records of mammals, birds, fish, butterflies and moths, dragonflies, rotifers, crustaceans and plants observed in the neighbourhood of Oundle. An interesting account of laboratory animals shows that axolotls, African clawed toads, stick insects, salamanders, eyed lizards and geckoes, various British lizards and tropical fish were all under observation some time during 1956.

\section{OXFORD BOTANIC GARDEN}

$T$ HE Botanic Garden at Oxford, which is the oldest in Britain, was founded and endowed as a Physic Garden by the Earl of Danby in 1621 . The Garden was intended for "the improvement of learning" with special regard for the study of 'simples' or drug plants. It was laid out on the site of the old Jews' burying ground opposite Magdalen College, from which the Garden is still leased by the University.

In 1642 the Garden was ready, and Danby, having failed to secure the services of the King's gardener, John Tradescant, appointed Jacob Bobart, an old Brunswick soldier, as 'Keeper'-indeed, as 'Hereditary Keeper'. During the difficult years that followed, Bobart began to collect garden plants, mainly for their interest in medicine, and in 1648 he published a catalogue of 600 native British plants and twice as many from abroad.

A professor of botany was appointed by Charles II in 1669 but the post was not endowed, and the care of the Garden and even the duties of teaching largely lay in the hands of Bobart and later of his son; the younger Bobart made some of the first experiments on sexual reproduction, using male and female plants of the indigenous campion. Many of the plants that he cultivated, especially West Indian ferns, are probably growing in the Garden to-day.

Fifteen years after the death of Bobart a chair of botany was finally endowed by William Sherard. The new professors followed the custom of the century rather than the example of Bobart : teaching ceased. The herbarium grew, but the plants were neglected. In these circumstances, it was by instinct rather than by instruction that Gilbert White, the naturalist, and Sir Joseph Banks, who later founded and stocked the gardens at Kew, visited the Physic Garden as undergraduates and gained a not too favourable impression of botany as a systematic study. 